\title{
Potential enhancing effects of a carbohydrase mixture on phytase efficacy in late-phase laying hens fed wheat-based diets
}

\author{
M. Mirzaee ${ }^{1}$, M. Torki $^{1 \#} \&$ M. Habibian ${ }^{1,2}$ \\ ${ }^{1}$ Department of Animal Science, College of Agriculture and Natural Resources, Razi University, Kermanshah, Iran \\ ${ }^{2}$ Department of Animal Science, Faculty of Agriculture, University of Kurdistan, Sanandaj, Iran
}

(Received 6 October 2014; Accepted 2 March 2015; First published online 22 July 2015)

\begin{abstract}
Copyright resides with the authors in terms of the Creative Commons Attribution 2.5 South African Licence.
See: http://creativecommons.org/licenses/by/2.5/za
Condition of use: The user may copy, distribute, transmit and adapt the work, but must recognise the authors and the South African
Journal of Animal Science.
\end{abstract}
\begin{abstract}
A total of 360 65-week-old Lohmann LSL-Lite laying hens were used in a six-week experiment to examine the potential enhancing effects of a commercial carbohydrase preparation on phytase efficacy. Two cultivars of wheat (Marvdasht and Sardari) were used to formulate basal diets containing $2.2 \mathrm{~g}$ or $2.9 \mathrm{~g}$ nonphytate phosphorus (NPP)/kg levels. A further eight dietary treatments were formulated by supplementing these diets with a commercial source of phytase individually or together with a carbohydrase preparation, resulting in 12 dietary treatments in a $2 \times 2 \times 3$ factorial arrangement. The production performance and egg quality traits were not affected by treatments. Birds receiving a diet with Marvdasht cultivar and $2.2 \mathrm{~g} \mathrm{NPP} / \mathrm{kg}$ exhibited the highest serum concentration of thyroxine. The lymphocyte and eosinophil counts increased and the heterophil counts and the ratio of heterophils to lymphocytes decreased in birds receiving phytase supplementation compared with those receiving phytase and carbohydrase simultaneously. According to the results, the supplementation of wheat-based diets with enzymes in the late phase of egg production does not affect productive performance of laying hens. However, enzymes may have special effects on bird health.
\end{abstract}

Keywords: Cereal, performance, phosphorus, triticum cultivars, wheat cultivar, xylanase

\# Corresponding author: torki@razi.ac.ir

\section{Introduction}

Wheat is a major ingredient in laying hen diet in many countries, because of its high protein and starch content compared with many other grains (Svihus \& Hetland, 2001). However, wheat, like most other vegetable feed ingredients, is not a good source of phosphorus $(P)$ because most of its $P$ is bound to phytic acid, which is poorly digested by hens (Bedford, 2000). The presence of phytic acid in wheat can negatively influence protein and amino acid digestibilities by preventing the activities of proteolytic enzymes such as pepsin and trypsin (Woyengo \& Nyachoti, 2013). Furthermore, phytic acid has a higher P content and chelating ability, so a phytate form of phytic acid diminishes the availability of calcium (Ca) and P (Wu et al., 2006). In addition to phytic acid, wheat contains non-starch polysaccharides (NSP) in its cell walls, which are poorly digestible and capable of reducing nutrient digestibility by encapsulation and by increasing digesta viscosity (Kim et al., 2005). Thus, phytic acid and NSP in wheat can reduce efficiency of nutrient utilization and increase environmental pollution because of excessive excretion of unabsorbed nutrients, especially nitrogen and P (Lenis \& Jongbloed, 1999).

Supplementation of wheat-based diets with phytase and xylanase may alleviate the negative effects of phytic acid and NSP, because phytase and NSP depolymerizing enzymes can hydrolyse phytic acid and arabinoxylans, respectively (Bedford, 2000). In wheat, both phytic acid and arabinoxylans are highly concentrated in the aleurone cells (Joyce et al., 2005). Phytase and xylanase could thus act synergistically in improving the nutritive value of wheat-based diets for laying hens because xylanase can hydrolyse arabinoxylans in cell walls to release phytic acid for action of phytase.

However, reports on the effect of combining phytase and xylanase in wheat-based diets are inconsistent. For example, Selle et al. (2003) reported synergism between the two enzymes in broilers, but Silversides et al. (2006) did not show similar effects in laying hens. The reasons for the discrepancies among authors are not known, but probably depend on the age of the animal, the characteristics of the wheat and the enzyme sources and their associated activities. Starch is the main component of wheat, but its nutritional contribution to the diet depends on the proportion of amylose and amylopectin, as well as the amount of resistant starch (McCleary, 2003). In addition, the NSP content of wheat, especially of arabinoxylans, is 
variable, depending on factors such as cultivar, environmental aspects and storage conditions after harvest (Gutierrez-Alamo et al., 2008a). Parsaie et al. (2006) reported that Iranian wheats are variable in their apparent metabolizable energy (AME), NSP, crude protein (CP) and other chemical components. Rafuse et al. (2005) reported that the CP of five varieties of Canadian wheat varied between $114 \mathrm{~g} / \mathrm{kg}$ to $155 \mathrm{~g} / \mathrm{kg}$. Moreover, some wheat cultivars that are regarded as being of high quality have produced broilers with unexpectedly low performance (Gutierrez-Alamo et al., 2008b).

As stated, enzyme supplementation can change the nutritional status and improve the productive performance of birds fed wheat-included diets, but these are closely related to the regulation of the metabolism and functioning of the growth-related endocrine system. For example, triiodothyronine (T3) and thyroxine (T4) in peripheral blood of laying hens play physiological functions in many ways, such as facilitating the differentiation, growth and development of tissue, promoting the formation of protein and enzymes, increasing the utilization of carbohydrates and enhancing the disintegration of fat (Ooi et al., 2004). Nutritional status is an important factor in the regulation of plasma hormones and intermediary metabolism in laying hens (Swennen et al., 2005; Xiao-Ying et al., 2010). The authors hypothesized that the effects of enzyme supplementation on productive performance may be associated with changes in the concentration of metabolic hormones and metabolites in laying hens fed wheat-based diets. Until now, no studies have been conducted to determine the effects of enzyme supplementation to wheat-based diets on circulating hormone and metabolite levels of laying hens.

The objective of the study was to examine the effects of dietary nonphytate P (NPP) level and phytase supplementation alone or together with a commercial carbohydrase preparation with mostly xylanase activity on the performance, egg quality traits and selected blood parameters of laying hens fed diets based on two wheat cultivars.

\section{Materials and Methods}

All procedures used in this six-week experiment were approved by the Animal Ethics Committee of Razi University and complied with the Guidelines for the Care and Use of Animals in Research.

Table 1 Nutrient analysis of the two wheat cultivars used in the study (as fed basis)

\begin{tabular}{|c|c|c|}
\hline \multirow{2}{*}{ Item $^{2}$} & \multicolumn{2}{|c|}{ Cultivar } \\
\hline & Marvdasht & Sardari \\
\hline Dry matter (g/kg) & 908 & 900 \\
\hline Ash (g/kg) & 15.1 & 30.3 \\
\hline Ether extract $(\mathrm{g} / \mathrm{kg})$ & 12.9 & 13.2 \\
\hline Crude fibre (g/kg) & 33.3 & 26.3 \\
\hline Crude protein (g/kg) & 118 & 111 \\
\hline Nitrogen free extract $(\mathrm{g} / \mathrm{kg})$ & 729 & 720 \\
\hline Starch (g/kg) & 699 & 692 \\
\hline Soluble NSP (g/kg) & 13.0 & 18.5 \\
\hline Non-soluble NSP (g/kg) & 83.0 & 120.0 \\
\hline Total NSP (g/kg) & 96.0 & 139.0 \\
\hline $\mathrm{AME}_{\mathrm{n}}(\mathrm{MJ} / \mathrm{kg})$ & 13.2 & 12.9 \\
\hline
\end{tabular}

Two cultivars of wheat were selected: Sardari is a soft white winter wheat cultivar and is one of the most important landraces of common wheat. It is cultivated mainly in drylands and mountainous area of Iran. Marvdasht is a hard red spring wheat cultivar, which is sown widely in southwest and central Iran because of its satisfactory yield and excellent bread-making quality. The two cultivars came from the Agriculture and Natural Resources Centre of Kermanshah in 2009. The nutrient analysis of the wheat samples (Table 1) was 
carried out according to the standard procedures of the AOAC (1995). The AME contents were estimated according to the National Research Council (NRC, 1994).

A total of 360 65-week-old Lohmann LSL-Lite laying hens with similar bodyweight and egg production rate was randomly distributed in 60 wire-floored cages and assigned to one of 12 experimental diets with four replicates and six hens per replicate. Each of the wheat cultivars was used to formulate basal diets containing either 2.2 or $2.9 \mathrm{~g} \mathrm{NPP} / \mathrm{kg}$ levels (Table 2). A further eight dietary treatments were made by supplementing each of these four diets with a commercial preparation of phytase $\left(0.1 \mathrm{~g}\right.$ Phyzyme ${ }^{\circledR}$ XP 5000 G/kg: contained 5000 FTU phytase/g) individually or together with a commercial preparation of carbohydrases (0.3 g Grindazym ${ }^{\circledR}$ GP 15 000/kg: 36000 FXU endo-1, 4- $\beta$-xylanase and 15000 BGU endo-1, 4- $\beta$-glucanase/g), resulting in 12 dietary treatments in a $2 \times 2 \times 3$ factorial arrangement. The cages were located in an environmentally controlled room with room temperature being kept at $21^{\circ} \mathrm{C}$ to $23^{\circ} \mathrm{C}$ and the photoperiod set at $16 \mathrm{~h}$ of light (incandescent lighting, $10 \mathrm{~lx}$ ) and $8 \mathrm{~h}$ dark.

Production performance of the laying hens was measured from 65 weeks to 71 weeks old. Egg production and egg weight were recorded daily for each replicate, and at the end of the each three experimental weeks, the total number of eggs laid per bird and the average egg weight per bird were calculated. The data were used to calculate egg mass per bird (egg number in replicate $\times$ average egg weight). Abnormal eggs, such as soft-shelled, cracked and broken, were recorded daily. Feed intake and

Table 2 Ingredients and nutrient composition of the experimental diets ( $\mathrm{g} / \mathrm{kg}$ of diet, unless otherwise noted)

\begin{tabular}{|c|c|c|c|c|}
\hline & \multicolumn{4}{|c|}{ Wheat cultivar } \\
\hline & \multicolumn{2}{|c|}{ Sardari } & \multicolumn{2}{|c|}{ Marvdasht } \\
\hline & $2.2 \mathrm{~g} \mathrm{NPP}$ & $2.9 \mathrm{~g} \mathrm{NPP}$ & $2.2 \mathrm{~g} \mathrm{NPP}$ & $2.9 \mathrm{~g} \mathrm{NPP}$ \\
\hline \multicolumn{5}{|l|}{ Ingredients } \\
\hline Wheat & 729 & 730 & 723 & 723 \\
\hline Soybean meal & 147 & 144 & 136 & 136 \\
\hline Soybean oil & 16.8 & 16.8 & 16.8 & 16.8 \\
\hline Oyster shell & 50.0 & 50.0 & 50.0 & 50.0 \\
\hline Limestone & 44.1 & 41.9 & 44.1 & 41.9 \\
\hline Dicalcium phosphate & 4.30 & 8.10 & 4.50 & 8.20 \\
\hline Common salt & 2.30 & 2.30 & 2.30 & 2.30 \\
\hline Sand & 0.70 & 0.70 & 16.8 & 15.3 \\
\hline Vit.-mineral premix ${ }^{1}$ & 5.00 & 5.00 & 5.00 & 5.00 \\
\hline DL-methionine & 1.00 & 1.00 & 1.00 & 1.00 \\
\hline Lysine-HCL & 0.10 & 0.20 & 0.30 & 0.30 \\
\hline \multicolumn{5}{|l|}{ Nutrient composition } \\
\hline Apparent ME (MJ/kg) & 11.4 & 11.4 & 11.4 & 11.4 \\
\hline Crude protein & 146 & 146 & 146 & 146 \\
\hline Calcium & 37.5 & 37.5 & 37.5 & 37.5 \\
\hline Lysine & 6.50 & 6.50 & 6.50 & 6.50 \\
\hline Methionine & 3.00 & 3.00 & 3.00 & 3.00 \\
\hline Methionine + cysteine & 5.60 & 5.60 & 5.60 & 5.60 \\
\hline Linoleic acid & 12.6 & 12.6 & 12.6 & 12.6 \\
\hline \multicolumn{5}{|c|}{$\begin{array}{l}{ }^{1} \text { Mineral-vitamin premix (/kg diet): } 20 \mathrm{mg} \mathrm{Cu} ; 100 \mathrm{mg} \mathrm{Fe} ; 100 \mathrm{mg} \mathrm{Mn} ; 0.4 \mathrm{mg} \mathrm{Se} ; 169.4 \mathrm{mg} \mathrm{Zn;} 1800 \mathrm{IU} \\
\text { vitamin A; } 4000 \mathrm{IU} \text { vitamin } \mathrm{D}_{3} ; 36 \mathrm{mg} \text { vitamin } \mathrm{E} ; 4 \mathrm{mg} \text { vitamin } \mathrm{K} ; 0.03 \mathrm{mg} \text { vitamin } \mathrm{B}_{12} ; 1.8 \mathrm{mg} \text { thiamine; } \\
13.2 \mathrm{mg} \text { riboflavin; } 6 \mathrm{mg} \text { pyridoxine; } 60 \mathrm{mg} \text { niacin; } 20 \mathrm{mg} \text { calcium pantothenate; } 2 \mathrm{mg} \text { folic acid; } 0.2 \mathrm{mg} \\
\text { biotin; } 500 \mathrm{mg} \text { choline chloride. } \\
\text { ME: metabolizable energy; NPP: nonphytate phosphorus. }\end{array}$} \\
\hline
\end{tabular}




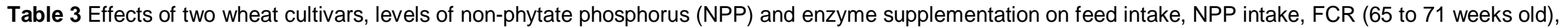
bodyweight and mortality percentage of laying hens

\begin{tabular}{|c|c|c|c|c|c|c|c|c|c|c|c|c|}
\hline \multirow{2}{*}{ Treatments } & \multicolumn{3}{|c|}{ Feed intake (g/hen/d) } & \multicolumn{3}{|c|}{ NPP intake $(g / h e n / d)^{1}$} & \multicolumn{3}{|c|}{ FCR (g egg/g feed) } & \multicolumn{2}{|c|}{ Body weight (g) } & \multirow{2}{*}{ Mortality (\%) } \\
\hline & Wk 1 - 3 & Wk 4 - 6 & Wk 1 - 6 & Wk 1 - 3 & Wk 4 - 6 & Wk 1 - 6 & Wk 1 - 3 & Wk 4 - 6 & Wk 1 - 6 & Initial & Final & \\
\hline \multicolumn{13}{|l|}{ Wheat cultivar } \\
\hline Marvdasht & 115 & 114 & 115 & 2.94 & 2.94 & 2.91 & 2.40 & 2.48 & 2.43 & 1389 & 1434 & 5.00 \\
\hline Sardari & 115 & 115 & 116 & 2.95 & 2.95 & 2.93 & 2.38 & 2.47 & 2.42 & 1408 & 1441 & 2.78 \\
\hline \multicolumn{13}{|l|}{ NPP (g/kg) } \\
\hline 2.2 & 115 & 114 & 115 & $2.54^{b}$ & $2.55^{b}$ & $2.53^{b}$ & 2.40 & 2.48 & 2.43 & 1394 & 1438 & 3.33 \\
\hline 2.9 & 115 & 115 & 115 & $3.35^{\mathrm{a}}$ & $3.32^{\mathrm{a}}$ & $3.32^{\mathrm{a}}$ & 2.38 & 2.47 & 2.42 & 1403 & 1437 & 4.45 \\
\hline \multicolumn{13}{|l|}{ Enzyme } \\
\hline- & 115 & 114 & 115 & 2.94 & 2.94 & 2.92 & 2.34 & 2.43 & 2.37 & 1395 & 1433 & 3.33 \\
\hline Phyzyme $^{2}$ & 115 & 115 & 115 & 2.94 & 2.95 & 2.92 & 2.48 & 2.49 & 2.48 & 1400 & 1437 & 2.50 \\
\hline Grindazym $^{3}$ & 116 & 115 & 115 & 2.95 & 2.95 & 2.93 & 2.35 & 2.51 & 2.42 & 1399 & 1442 & 5.84 \\
\hline SEM & 0.43 & 0.46 & 0.41 & 0.518 & 0.504 & 0.511 & 0.037 & 0.042 & 0.036 & 5.5 & 5.4 & 0.169 \\
\hline Sources of variation ${ }^{4}$ & & & & & & $P$-values & & & & & & \\
\hline Wheat cultivar & 0.56 & 0.10 & 0.24 & 0.62 & 0.83 & 0.41 & 0.80 & 0.95 & 0.85 & 0.11 & 0.56 & 0.23 \\
\hline NPP & 0.97 & 0.46 & 0.70 & $<0.0001$ & $<0.0001$ & $<0.0001$ & 0.78 & 0.89 & 0.84 & 0.46 & 0.97 & 0.55 \\
\hline Enzyme & 0.83 & 0.94 & 0.89 & 0.82 & 0.97 & 0.97 & 0.314 & 0.75 & 0.56 & 0.94 & 0.83 & 0.32 \\
\hline
\end{tabular}

Means within column with different superscripts are significantly different $(P<0.05)$, Duncan's multiple-range test were applied to compare means

SEM: standard error of mean;

Wk: week; FCR: feed conversion ratio.

Calculations based on dietary NPP concentration

$0.1 \mathrm{~g}$ Phyzyme ${ }^{\circledR}$ XP $5000 \mathrm{G} / \mathrm{kg}$ of diet: contained 5000 FTU phytase activity/g;

${ }^{3} 0.3 \mathrm{~g}$ Grindazym ${ }^{\circledR}$ GP 15 000/kg of diet: 36000 FXU endo-1, 4- $\beta$-xylanase and 15000 BGU endo-1, 4- $\beta$-glucanase activity/g.

${ }^{4}$ Interactions were not significant $(P>0.05)$. 
Table 4 Effects of two wheat cultivars, levels of non-phytate phosphorus (NPP) and enzyme supplementation on egg production, egg weight and egg mass of laying hens (65 to 71 weeks old)

\begin{tabular}{|c|c|c|c|c|c|c|c|c|c|}
\hline \multirow{2}{*}{ Treatments } & \multicolumn{3}{|c|}{$\begin{array}{c}\text { Egg production } \\
(\%)\end{array}$} & \multicolumn{3}{|c|}{$\begin{array}{l}\text { Egg weight } \\
\text { (g) }\end{array}$} & \multicolumn{3}{|c|}{$\begin{array}{l}\text { Egg mass } \\
\text { (g/hen/d) }\end{array}$} \\
\hline & Wk 1 - 3 & Wk 4 - 6 & Wk 1 - 6 & Wk 1 - 3 & Wk 4 - 6 & Wk 1 - 6 & Wk 1 - 3 & Wk 4 - 6 & Wk 1 - 6 \\
\hline \multicolumn{10}{|l|}{ Wheat cultivar } \\
\hline Marvdasht & 77.3 & 74.6 & 76.0 & 63.2 & 62.8 & 63.0 & 48.9 & 46.8 & 47.8 \\
\hline Sardari & 77.2 & 75.0 & 76.1 & 63.7 & 63.2 & 63.4 & 49.2 & 47.4 & 48.3 \\
\hline \multicolumn{10}{|l|}{ NPP (g/kg) } \\
\hline 2.2 & 77.0 & 75.0 & 76.0 & 63.3 & 63.0 & 63.1 & 48.7 & 47.3 & 48.0 \\
\hline 2.9 & 77.5 & 74.6 & 76.1 & 63.6 & 62.9 & 63.3 & 49.3 & 47.0 & 48.1 \\
\hline \multicolumn{10}{|l|}{ Enzyme } \\
\hline- & 78.0 & 75.7 & 76.9 & 63.6 & 63.2 & 63.4 & 49.6 & 47.8 & 48.7 \\
\hline Phyzyme $^{1}$ & 75.3 & 74.4 & 74.8 & 63.0 & 62.9 & 62.9 & 47.4 & 46.8 & 47.1 \\
\hline Grindazym $^{2}$ & 78.5 & 74.3 & 76.4 & 63.7 & 62.9 & 63.3 & 50.0 & 46.7 & 48.3 \\
\hline SEM & 1.04 & 1.11 & 1.00 & 0.25 & 0.23 & 0.22 & 0.69 & 0.74 & 0.66 \\
\hline Sources of variation ${ }^{3}$ & & & & & $P$-values & & & & \\
\hline Wheat cultivar & 0.95 & 0.86 & 0.98 & 0.42 & 0.40 & 0.37 & 0.85 & 0.69 & 0.76 \\
\hline NPP & 0.82 & 0.88 & 0.95 & 0.52 & 0.85 & 0.79 & 0.71 & 0.83 & 0.94 \\
\hline Enzyme & 0.47 & 0.86 & 0.73 & 0.49 & 0.86 & 0.72 & 0.33 & 0.82 & 0.65 \\
\hline
\end{tabular}

SEM: standard error of mean; Wk: week.

${ }^{1} 0.1 \mathrm{~g}$ Phyzyme ${ }^{\circledR}$ XP $5000 \mathrm{G} / \mathrm{kg}$ of diet: contained 5000 FTU phytase activity/g;

$20.3 \mathrm{~g}$ Grindazym ${ }^{\circledR}$ GP $15000 / \mathrm{kg}$ of diet: 36000 FXU endo-1, 4- $\beta$-xylanase and 15000 BGU endo- $1,4-\beta$-glucanase activity/g.

3 Interactions were not significant $(P>0.05)$. 
estimated NPP intake were measured weekly. Data on feed intake and egg mass were used to calculate feed conversion ratio ( $F C R$; feed intake/egg mass, $\mathrm{g} / \mathrm{g}$ ). Bodyweights were recorded at the beginning and end of the experiment, while mortality was recorded daily.

All the eggs laid during the last three days of the experiment were collected to measure the egg quality traits. Egg specific gravity, eggshell weight, eggshell thickness, albumen height and yolk colour were measured on 10 eggs from each treatment (2 eggs per replicate). Egg specific gravity was determined using 11 gradient saline solutions varying in specific gravity from 1.060 to 1.100 at 0.005-unit increments (Holder \& Bradford, 1979), where water temperature was maintained between $15{ }^{\circ} \mathrm{C}$ and $17{ }^{\circ} \mathrm{C}$. Eggshell thickness was measured with a FHK device (Fujihira Co. Ltd., Tokyo, Japan). Albumen height was documented at three sites with a spherometer. Haugh units (Eisen et al., 1962) were calculated by the formula:

$\mathrm{HU}=100 \log \left(\mathrm{H}+7.57-1.7 \mathrm{~W}^{0.37}\right)$.

Yolks were separated with an egg separator and weighed. Albumen weight was calculated by subtracting the yolk and eggshell weight from the total egg weight. The yolk index was determined as the ratio of yolk height to yolk width and yolk colour was compared to the Roche yolk colour fan, which ranges from pale yellow at score 1 to dark orange at score 15 (Vuilleumier, 1969).

Blood samples were collected from the wing vein of six randomly selected birds per treatment (one hen per replicate) at the end of the experiment. The blood samples for differential counts of white blood cells were collected into bottles pre-treated with heparin as anti-coagulant. After providing the blood smear and staining by May-Grünwald-Giemsa stain, differential counting of white blood cells was done using a light microscope, and the heterophil to lymphocyte $(\mathrm{H} / \mathrm{L})$ ratio was calculated (Gross \& Siegel, 1983). Blood samples for serum metabolites were collected into sample bottles containing no anti-coagulant and centrifuged (15 min, $3000 \mathrm{rpm})$. The sera were removed and stored at $-20^{\circ} \mathrm{C}$ until further analysis. Serum glucose and triglycerides were analysed using diagnostic kits (Pars Azmun, Tehran, Iran), and enzymatic methods, while serum T3 and T4 were measured by an ELISA kit (Pishtaz Teb, Tehran, Iran).

Data were subjected to ANOVA in a completely randomized design with a $2 \times 2 \times 3$ factorial arrangement of treatments using the GLM procedure of SAS (2003). All statements of significance are based a $P<0.05$. The mean values were compared with Duncan's multiple-range test. The following model was considered for analysis:

$$
Y_{i j k l}=\mu+A_{i}+B_{j}+C_{k}+(A B)_{i j}+(A C)_{i k}+(B C)_{j k},+(A B C)_{i j k}+\varepsilon_{i j k l}
$$

where: $Y_{i j k l}$ is the characteristic that was measured, $\mu$ is the overall mean; $A_{i}$ is main effect of the wheat cultivar; $B_{j}$ is the main effect of NPP; $C_{k}$ is the main effect of enzyme; $(A B)_{i j}$ is the effect of the interaction between wheat cultivar and NPP; $(A C)_{i k}$ is the effect of the interaction between wheat cultivar and enzyme; $(B C)_{j k}$ is the effect of the interaction between NPP and enzyme; $(A B C)_{i j k}$ is the three-way interaction of the wheat cultivar, NPP and enzyme; and $\varepsilon_{\mathrm{ijkl}}$ is the random error term. Where the interaction effect was significant, the effects of the main factors were not discussed.

\section{Results}

The effects of dietary treatments on performance production of laying hens are presented in Tables 3 and 4. No significant difference was observed in feed intake among the birds receiving different dietary treatments $(P>0.05)$. However, NPP intake was increased because of feeding diets containing $2.9 \mathrm{~g} \mathrm{NPP} / \mathrm{kg}(P<0.05)$. Nevertheless, the birds receiving different dietary treatments did not differ significantly in egg production, egg weight, egg mass, FCR, bodyweight, and mortality rate during the experiment $(P>0.05)$.

Data on egg quality traits are shown in Table 5 . Dietary treatments had no significant effect on percentage of abnormal eggs, eggshell weight or thickness and egg specific gravity $(P>0.05)$. Similarly, egg shape index, Haugh unit and egg yolk index were not affected by dietary treatments $(P>0.05)$.

As shown in Table 6, dietary treatments had no influence on serum biochemical concentrations $(P>0.05)$, except for serum T4 concentration, which was affected by wheat cultivar $\times$ NPP $\times$ enzyme interaction $(P<0.05)$. The nature of this interaction showed that birds receiving a diet with Marvdasht cultivar and $2.2 \mathrm{~g} \mathrm{NPP} / \mathrm{kg}$ level exhibited higher serum concentration of T4 compared with those receiving a diet with Sardari cultivar and the same NPP level $(P<0.05)$. Both enzyme supplementation and higher NPP level decreased serum concentration of T4 when birds received a diet with Marvdasht cultivar $(P<0.05)$. Conversely, phytase supplementation increased serum concentration of T4 when birds received a lower NPP level or a diet with Sardari cultivar $(P<0.05)$. 
Table 5 Effects of two wheat cultivars, levels of non-phytate phosphorus (NPP) and enzyme supplementation on egg quality traits of laying hens (71 weeks old)

\begin{tabular}{|c|c|c|c|c|c|c|c|c|}
\hline Treatments & $\begin{array}{c}\text { Abnormal eggs }^{1} \\
(\%)\end{array}$ & $\begin{array}{c}\text { Shell weight } \\
(\%)\end{array}$ & $\begin{array}{c}\text { Shell thickness } \\
\left(\mathrm{mm} \times 10^{-2}\right)\end{array}$ & Specific gravity & Egg index & Haugh unit & $\begin{array}{c}\text { Yolk colour } \\
\text { (Roche) }\end{array}$ & Yolk index \\
\hline \multicolumn{9}{|l|}{ Wheat cultivar } \\
\hline Marvdasht & 2.39 & 5.91 & 37.6 & 1.08 & 76.6 & 84.8 & 1.30 & 44.2 \\
\hline Sardari & 2.28 & 5.90 & 37.7 & 1.08 & 76.3 & 84.7 & 1.23 & 44.2 \\
\hline \multicolumn{9}{|l|}{ NPP (g/kg) } \\
\hline 2.2 & 2.76 & 5.89 & 37.6 & 1.08 & 76.4 & 84.5 & 1.23 & 43.8 \\
\hline 2.9 & 1.90 & 5.92 & 37.7 & 1.08 & 76.5 & 85.0 & 1.30 & 44.6 \\
\hline \multicolumn{9}{|l|}{ Enzyme } \\
\hline- & 1.61 & 5.91 & 37.6 & 1.08 & 76.1 & 82.8 & 1.35 & 44.1 \\
\hline Phyzyme $^{2}$ & 2.37 & 5.91 & 37.7 & 1.08 & 76.4 & 85.7 & 1.15 & 44.4 \\
\hline Grindazym $^{3}$ & 3.02 & 5.90 & 37.7 & 1.08 & 76.8 & 85.8 & 1.30 & 44.1 \\
\hline SEM & 0.265 & 0.024 & 0.16 & 0.001 & 0.41 & 0.57 & 0.205 & 0.24 \\
\hline Sources of variation ${ }^{4}$ & & & & $P$-values & & & & \\
\hline Wheat cultivar & 0.85 & 0.68 & 0.83 & 0.62 & 0.72 & 0.93 & 0.58 & 0.94 \\
\hline NPP & 0.14 & 0.41 & 0.76 & 0.87 & 0.89 & 0.69 & 0.58 & 0.07 \\
\hline Enzyme & 0.14 & 0.98 & 0.94 & 0.70 & 0.85 & 0.11 & 0.38 & 0.82 \\
\hline
\end{tabular}

SEM: standard error of mean.

${ }_{2}^{1}$ Percentage of all cracked, broken, soft-shelled eggs and eggs that lacked shells of total laid eggs.

${ }^{2} 0.1 \mathrm{~g}$ Phyzyme ${ }^{\circledR}$ XP $5000 \mathrm{G} / \mathrm{kg}$ of diet: contained $5000 \mathrm{FTU}$ phytase activity/g;

${ }^{3} 0.3 \mathrm{~g}$ Grindazym ${ }^{\circledR}$ GP 15 000/kg of diet: 36000 FXU endo-1, 4- $\beta$-xylanase and 15000 BGU endo-1, 4- $\beta$-glucanase activity/g.

${ }^{4}$ Interactions were not significant $(P>0.05)$. 
Table 6 Effects of two wheat cultivars, levels of non-phytate phosphorus (NPP) and enzyme supplementation on serum biochemical concentrations of laying hens laying hens (71 weeks old)

\begin{tabular}{|c|c|c|c|c|c|}
\hline Treatments & Glucose (mg/dL) & $\begin{array}{c}\text { Triglycerides } \\
\text { (mg/dL) }\end{array}$ & $\begin{array}{c}\text { T3 } \\
\text { (ng/mL) }\end{array}$ & $\begin{array}{c}\mathrm{T} 4 \\
\text { (ng/mL) }\end{array}$ & $\begin{array}{c}\text { T3/T4 } \\
(\%)\end{array}$ \\
\hline \multicolumn{6}{|l|}{ Wheat cultivar } \\
\hline Marvdasht & 240.9 & 1578 & 0.70 & 11.0 & 6.68 \\
\hline Sardari & 239.1 & 1826 & 0.73 & 11.7 & 6.87 \\
\hline \multicolumn{6}{|l|}{ NPP $(g / k g)$} \\
\hline 2.2 & 240.1 & 1667 & 0.71 & 12.2 & 6.58 \\
\hline 2.9 & 240.1 & 1702 & 0.71 & 10.4 & 6.98 \\
\hline \multicolumn{6}{|l|}{ Enzyme } \\
\hline- & 259.3 & 1815 & 0.74 & 12.2 & 6.85 \\
\hline Phyzyme ${ }^{1}$ & 217.2 & 1598 & 0.72 & 11.7 & 6.81 \\
\hline Grindazym $^{2}$ & 246.3 & 1644 & 0.66 & 10.0 & 6.63 \\
\hline SEM & 7.91 & 113.0 & 0.039 & 0.62 & 0.424 \\
\hline Sources of variation ${ }^{3}$ & \multicolumn{5}{|c|}{$P$-values } \\
\hline Wheat cultivar & 0.74 & 0.43 & 0.73 & 0.73 & 0.83 \\
\hline NPP & 0.95 & 0.90 & 0.84 & 0.19 & 0.79 \\
\hline Enzyme & 0.22 & 0.77 & 0.69 & 0.35 & 0.96 \\
\hline
\end{tabular}

SEM: standard error of mean.

T3: triiodothyronine; T4: thyroxine.

${ }^{1} 0.1 \mathrm{~g}$ Phyzyme ${ }^{\mathrm{X}}$ XP 5 000G/kg of diet: contained $5000 \mathrm{FTU}$ phytase activity $/ \mathrm{g}$;

$20.3 \mathrm{~g}$ Grindazym ${ }^{\circledR}$ GP 15 000/kg of diet: 36000 FXU endo-1, 4- $\beta$-xylanase and 15000 BGU endo-1, 4- $\beta$-glucanase activity/g.

${ }^{3}$ Interactions were not significant $(P>0.05)$ except for three-way interaction on T4 concentration.

The effects of dietary treatments on differential counts of white blood cells and $\mathrm{H} / \mathrm{L}$ ratio are shown in Table 7. The lymphocyte and eosinophil counts increased $(P<0.05)$ and the heterophil counts and $\mathrm{H} / \mathrm{L}$ ratio decreased $(P<0.05)$ in birds receiving phytase supplementation compared with those receiving phytase and xylanase supplementation simultaneously. The $\mathrm{H} / \mathrm{L}$ ratio and blood cell counts for birds receiving no supplemental enzyme were intermediate between these two groups $(P>0.05)$.

\section{Discussion}

The principal aim of this study was to examine the potential enhancing effects of a commercial enzyme source with mostly xylanase activity on phytase efficacy in laying hens fed diets based on two wheat cultivars. The literature data show in general a large variation in total P content, NPP content and phytase activity of wheat cultivars (Steiner et al., 2007). Moreover, in a survey of 18 wheat cultivars, Kim et al. (2003) found that starch content ranged between $585 \mathrm{~g} / \mathrm{kg}$ and $737 \mathrm{~g} / \mathrm{kg}, \mathrm{CP}$ between $97 \mathrm{~g} / \mathrm{kg}$ and $191 \mathrm{~g} / \mathrm{kg}$, and NSP between $78 \mathrm{~g} / \mathrm{kg}$ and $110 \mathrm{~g} / \mathrm{kg}$. Unfortunately, in the present study, the total $\mathrm{P}$ content and its fractions were not analysed. However, the two wheat cultivars had different NSP contents. Nevertheless, no significant difference was observed in performance criteria among birds receiving diets containing either the Marvdasht or the Sardari cultivar. Moreover, dietary NPP level and enzyme addition had no significant effect on performance production and there was no interaction between wheat cultivar, NPP level and enzyme on the performance criteria. This pattern differs from that described by other researchers (Keshavarz, 2003; Francesch et al., 2005; Silversides et al., 2006). Keshavarz (2003) and Francesch et al. (2005) found that low NPP levels decreased egg production, and that phytase reversed the effect. Silversides et al. (2006) reported that egg weight late in production was increased by phytase in P-reduced diets with xylanase, but not in the diets without xylanase, suggesting an interaction between the enzymes. Dietary NPP level could be considered among the factors responsible for these differences, because the diet used in the present study might not have been deficient in P. Nonphytate P intake of hens fed diets containing $2.2 \mathrm{~g} \mathrm{NPP} / \mathrm{kg}$ was around $2.53 \mathrm{~g} / \mathrm{hen} / \mathrm{d}$, which was close to NRC (1994) value of $2.5 \mathrm{~g} / \mathrm{hen} / \mathrm{d}$. However, when dietary NPP was 
Table 7 Effects of two wheat cultivars, levels of non-phytate phosphorus (NPP) and enzyme supplementation on differential counts of white blood cells of laying hens (71 weeks old)

\begin{tabular}{|c|c|c|c|c|c|c|}
\hline Treatments & Heterophil & Lymphocyte & Monocyte & Eosinophil & Basophil & $H / L$ ratio \\
\hline \multicolumn{7}{|l|}{ Wheat cultivar } \\
\hline Marvdasht & 36.3 & 60.7 & 0.90 & 0.72 & $1.17^{\mathrm{b}}$ & 0.63 \\
\hline Sardari & 34.6 & 62.6 & 0.52 & 0.76 & $1.68^{\mathrm{a}}$ & 0.56 \\
\hline \multicolumn{7}{|l|}{ NPP $(g / k g)$} \\
\hline 2.2 & 35.0 & 62.0 & 0.78 & 0.74 & 1.33 & 0.58 \\
\hline 2.9 & 36.0 & 61.2 & 0.67 & 0.74 & 1.48 & 0.61 \\
\hline \multicolumn{7}{|l|}{ Enzyme } \\
\hline- & $35.3^{\mathrm{ab}}$ & $61.7^{\mathrm{ab}}$ & 0.74 & $0.63^{\mathrm{ab}}$ & 1.53 & $0.58^{\mathrm{ab}}$ \\
\hline Phyzyme ${ }^{1}$ & $32.0^{\mathrm{b}}$ & $65.0^{\mathrm{a}}$ & 0.65 & $1.12^{\mathrm{a}}$ & 1.29 & $0.50^{\mathrm{b}}$ \\
\hline Grindazym $^{2}$ & $39.1^{\mathrm{a}}$ & $58.2^{\mathrm{b}}$ & 0.78 & $0.50^{\mathrm{b}}$ & 1.39 & $0.71^{\mathrm{a}}$ \\
\hline SEM & 0.87 & 0.82 & 0.112 & 0.097 & 0.113 & 0.026 \\
\hline Sources of variation ${ }^{3}$ & \multicolumn{6}{|c|}{$P$-values } \\
\hline Wheat cultivar & 0.38 & 0.26 & 0.11 & 0.87 & 0.04 & 0.24 \\
\hline NPP & 0.60 & 0.59 & 0.65 & 0.94 & 0.61 & 0.60 \\
\hline Enzyme & 0.01 & 0.01 & 0.93 & 0.05 & 0.78 & 0.01 \\
\hline
\end{tabular}

Means within columns with different superscripts differ significantly $(P<0.05)$, Duncan's multiple-range test were applied to compare means.

SEM: standard error of mean.

${ }^{1} 0.1 \mathrm{~g}$ Phyzyme ${ }^{2}$ XP $5000 \mathrm{G} / \mathrm{kg}$ of diet: contained $5000 \mathrm{FTU}$ phytase activity $/ \mathrm{g}$;

${ }^{2} 0.3 \mathrm{~g}$ Grindazym ${ }^{\circledR}$ GP 15 000/kg of diet: 36000 FXU endo-1, 4- $\beta$-xylanase and 15000 BGU endo-1, 4- $\beta$-glucanase activity/g.

${ }^{3}$ Interactions were not significant $(P>0.05)$.

$2.9 \mathrm{~g} / \mathrm{kg}$, NPP intake of hens increased to $3.33 \mathrm{~g} / \mathrm{hen} / \mathrm{d}$, which was much higher than the dietary NPP requirement of laying hens (NRC, 1994). Ahmadi \& Rodehutscord (2012) used a meta-analytical approach to describe the relationship between dietary levels of NPP and phytase in laying hens. Their results revealed that diets containing $2.2 \mathrm{~g} \mathrm{NPP} / \mathrm{kg}$ without supplemental phytase produce high performance with regard to egg production, egg mass and FCR. In the presence of 150, 300, and 400 FTU phytase/kg, the dietary NPP levels could be reduced, and optima were calculated as $1.8 \mathrm{~g} / \mathrm{kg}, 1.5 \mathrm{~g} / \mathrm{kg}$ and $1.4 \mathrm{~g} / \mathrm{kg}$, respectively.

Dietary treatments did not affect any of the egg quality traits. However, as expected, egg yolk colour was markedly lower than that normally reported for laying hens consuming maize-based diets (Pérez-Bonilla et al., 2012; Li et al., 2013). Similar to the results of the present study, Rafuse et al. (2004) observed that diets based on wheat with a mixture of xylanase and protease did not affect albumen height, yolk weight, eggshell weight or albumen weight when measured three weeks (32 weeks old) after the hens began to consume the experimental diets. In addition, as in the present experiment, Boling et al. (2000) showed that feeding diets containing $1.0 \mathrm{~g} \mathrm{NPP} / \mathrm{kg}, 1.5 \mathrm{~g} \mathrm{NPP} / \mathrm{kg}$ or $4.5 \mathrm{~g} \mathrm{NPP} / \mathrm{kg}$ without or with phytase supplementation had no effect on specific gravity. Zaghari (2009) showed no significant difference in Haugh unit, egg specific gravity, eggshell thickness and breaking strength or eggshell ash and Ca contents when the diet of laying hens was supplemented with 300 FTU phytase $/ \mathrm{kg}$. In contrast, Mirzaie et al. (2012) found that eggshell thickness at 47 weeks old was improved by xylanase supplementation in laying hens fed diets containing 230 to $690 \mathrm{~g}$ wheat $/ \mathrm{kg}$. Lim et al. (2003) and Hughes et al. (2008) found that low NPP levels $(1.5 \mathrm{~g} / \mathrm{kg}$ diet) increased production of abnormal eggs and that phytase reversed the effect, but both studies used lower levels of NPP than were used in this study.

Thyroid hormones play an important role in regulating general metabolism, growth and tissue differentiation, as well as gene expression (Ooi et al., 2004). Enzyme addition may directly or indirectly promote the activity of deiodinase in liver and kidney tissues, thus, promoting the transformation of T4 into T3 (Gao et al., 2008). In our present study, birds receiving a diet with Marvdasht cultivar and lower NPP level exhibited higher serum concentration of T4 compared with those receiving a diet with Sardari cultivar. Both enzyme supplementation and higher NPP level decreased serum concentration of T4 when birds received 
diets with Marvdasht cultivar. Conversely, phytase supplementation increased serum concentration of T4 when birds received the lower NPP level or diets with the Sardari cultivar. However, dietary treatments had no significant influence on serum concentrations of T3, glucose and triglycerides. These observations, in addition to the absence of significant differences between treatments on performance criteria, call into question the significance of observed differences between treatments for serum concentrations of T4. The mechanism of exogenous enzymes on hormone regulation is complicated and requires further and long-term studies.

The lymphocyte and eosinophil counts significantly increased and the heterophil counts and $\mathrm{H} / \mathrm{L}$ ratios significantly decreased in birds receiving dietary phytase supplementation compared with those receiving phytase and xylanase supplementation together, and the $\mathrm{H} / \mathrm{L}$ ratio and blood cell counts for birds receiving no supplemental enzyme were intermediate between these two groups. The $\mathrm{H} / \mathrm{L}$ ratio has been used as a reliable indicator of stress in poultry (Gross \& Siegel, 1983). Although the authors had no special stressor during this study, the observed effect of phytase supplementation on altering the $\mathrm{H} / \mathrm{L}$ ratio shows that phytase may act as a potential moderator of stress in poultry. In the literature, decreased H/L ratio is usually related to feed additives that have anti-free radical and antioxidant properties (Çetin et al., 2010; Habibian et al., 2014). Myoinositol phosphate intermediates with the conserved IP1,2,3 motif might have produced this effect. Antioxidative, protective against reactive oxygen species, functions of inositol 1,2,3-triphosphate and inositol 1,2,3,6-tetrakisphosphate are well documented (Phillippy \& Graf, 1997). Using an enzyme preparation with mostly xylanase activity, Mirzaee et al. (2014) reported no change in differential count of white blood cells in 71-week-old Lohmann LSL-Lite laying hens. However, it is not clear why the simultaneous use of phytase and xylanase reduced the percentage of lymphocytes, and as a result produced the highest $\mathrm{H} / \mathrm{L}$ ratio.

\section{Conclusions}

In this study, wheat cultivar, NPP level and use of phytase, either alone or in combination with xylanase, had no effect on hen performance. However, some difference was observed on serum T4 level and white blood cells counts among birds receiving dietary treatments. These results show that enzyme supplementation may have special effects on bird health. Further studies must be done to confirm these results and to clarify the mechanism of action.

\section{Acknowledgements}

This study was funded by Razi University (Kermanshah, Iran), which is greatly appreciated.

\section{References}

Ahmadi, H. \& Rodehutscord, M., 2012. A meta-analysis of responses to dietary nonphytate phosphorus and phytase in laying hens. Poult. Sci. 91, 2072-2078.

AOAC, 1995. Official methods of analysis (16th ed.). Association of Official Analytical Chemists, Inc., Arlington, Virginia, USA.

Bedford, M.R., 2000. Exogenous enzymes in monogastric nutrition-their current value and future benefits. Anim. Feed Sci. Technol. 86, 1-13.

Boling, S.D., Douglas, M.W., Johnson, M.L., Wang, X., Parsons, C.M., Koelkebeck, K.W. \& Zimmerman, R.A., 2000. The effects of dietary available phosphorus levels and phytase on performance of young and older laying hens. Poult. Sci. 79, 224-230.

Çetin, E., Silici, S., Çetin, N. \& Güçlü, B.K., 2010. Effects of diets containing different concentrations of propolis on hematological and immunological variables in laying hens. Poult. Sci. 89, 1703-1708.

Eisen, E.J., Bohren, B.B. \& McKean, H.E., 1962. The Haugh unit as a measure of egg albumen quality. Poult. Sci. 41, 1461-1468.

Francesch, M., Broz, J. \& Brufau, J., 2005. Effects of an experimental phytase on performance, egg quality, tibia ash content and phosphorus bioavailability in laying hens fed on maize-or barley-based diets. Br. Poult. Sci. 46, 340-348.

Gao, F., Jiang, Y., Zhou, G.H. \& Han Z.K., 2008. The effects of xylanase supplementation on performance, characteristics of the gastrointestinal tract, blood parameters and gut microflora in broilers fed on wheat-based diets. Anim. Feed Sci. Technol. 142, 173-184.

Gross, W.B. \& Siegel, H.S., 1983. Evaluation of the heterophil/lymphocyte ratio as a measure of stress in chickens. Avian Dis. 27, 972-978.

Gutierrez-Alamo, A., De Ayala, P.P., Verstegen, M.A.W., Hartog, L. \& Villamide, M.J., 2008a. Variability in wheat: factors affecting its nutritional value. World's Poult. Sci. J. 64, 20-39. 
Gutierrez-Alamo, A., Verstegen, M.W.A., Den Hartog, L.A., Perez de Ayala, P. \& Villamide, M.J., 2008b. Effect of wheat cultivar and enzyme addition to broiler chicken diets on nutrient digestibility, performance, and apparent metabolizable energy content. Poult. Sci. 87, 759-767.

Habibian, M., Ghazi, S., Moeini, M.M. \& Abdolmohammadi, A., 2014. Effects of dietary selenium and vitamin $E$ on immune response and biological blood parameters of broilers reared under thermoneutral or heat stress conditions. Int. J. Biometeorol. 58, 741-752.

Holder, D.P. \& Bradford, M.V., 1979. Relationship of specific gravity of chicken eggs to number of cracked eggs and percent shell. Poult. Sci. 58, 250-251.

Hughes, A.L., Dahiya, J.P., Wyatt, C.L. \& Classen, H.L., 2008. The efficacy of quantum phytase in a fortyweek production trial using white leghorn laying hens fed corn-soybean meal-based diets. Poult. Sci. 87, 1156-1161.

Joyce, C., Deneau, A., Peterson, K., Ockenden, I., Raboy, V. \& Lott, J.N., 2005. The concentrations and distributions of phytic acid phosphorus and other mineral nutrients in wild-type and low phytic acid Js-12-LPA wheat (Triticum aestivum) grain parts. Can. J. Bot. 83, 1599-1607.

Keshavarz, K., 2003. The effect of different levels of nonphytate phosphorus with and without phytase on the performance of four strains of laying hens. Poult. Sci. 82, 71-91.

Kim, J.C., Mullan, B.P., Simmins, P.H. \& Pluske, J.R., 2003. Variation in the chemical composition of wheats grown in Western Australia as influenced by variety, growing region, season and post-harvest storage. Aust. J. Agr. Res. 54, 541-550.

Kim, J.C., Simmins, P.H., Mullan, B.P. \& Pluske, J.R., 2005. The effect of wheat phosphorus content and supplemental enzymes on digestibility and growth performance of weaner pigs. Anim. Feed Sci. Technol. 118, 139-152.

Lenis, N.P. \& Jongbloed, A.W., 1999. New technologies in low pollution swine diets: Diet manipulation and use of synthetic amino acids, phytase and phase feeding for reduction of nitrogen and phosphorus excretion and ammonia emission. Asian-Aust. J. Anim. Sci. 12, 305-327.

Li, F., Zhang, L.M., Wu, X.H., Li, C.Y., Yang, X.J., Dong, Y., Lemme, A., Han, J.C. \& Yao, J.H., 2013. Effects of metabolizable energy and balanced protein on egg production, quality, and components of Lohmann Brown laying hens. J. Appl. Poult. Res. 22, 36-46.

Lim, H.S., Namkung, H. \& Paik, I.K., 2003. Effects of phytase supplementation on the performance, egg quality, and phosphorous excretion of laying hens fed different levels of dietary calcium and nonphytate phosphorous. Poult. Sci. 82, 92-99.

McCleary, B.V., 2003. Dietary fibre analysis. Proc. Nutr. Soc. 62, 3-9.

Mirzaee, M., Torki, M. \& Habibian, M., 2014. Effects of wheat cultivar, metabolizable energy level, and xylanase supplementation to laying hens diet on performance, egg quality traits, and selected blood parameters. Span. J. Agr. Res. 12, 1071-1081.

Mirzaie, S., Zaghari, M., Aminzadeh, S., Shivazad, M. \& Mateos, G.G., 2012. Effects of wheat inclusion and xylanase supplementation of the diet on productive performance, nutrient retention, and endogenous intestinal enzyme activity of laying hens. Poult. Sci. 91, 413-425.

NRC, 1994. Nutrient Requirements of Poultry (9th ed.). National Academy Press, Washington D.C., USA.

Ooi, G.T., Tawadros, N. \& Escalona, R.M., 2004. Pituitary cell lines and their endocrine applications. Mol. Cell. Endocrinol. 228, 1-21.

Parsaie, S., Shariatmadari, F., Zamiri, M.J. \& Khajeh, K., 2006. Evaluation of starch, soluble and insoluble non-starch polysaccharides and metabolizable energy of 15 cultivars of Iranian wheat. J. Agr. Soc. Sci. 2, 260-263.

Pérez-Bonilla, A., Novoa, S., García, J., Mohiti-Asli, M., Frikha, M. \& Mateos, G.G., 2012. Effects of energy concentration of the diet on productive performance and egg quality of brown egg-laying hens differing in initial body weight. Poult. Sci. 91, 3156-3166.

Phillippy, B.Q. \& Graf, E., 1997. Antioxidant functions of inositol 1,2,3-triphosphate and inositol 1,2,3,6-tetrakisphosphate. Free Radic. Biol. Med. 22, 936-946.

Rafuse, J.L., Silversides, F.G., Bedford, M.R. \& Simmins, P.H., 2004. Effect of wheat cultivar and enzyme supplementation on nutrient availability and performance of laying hens. Can. J. Anim. Sci. 84, 397-402.

Rafuse, J.L., Silversides, F.G., Bedford, M.R. \& Simmins, P.H., 2005. Effect of cultivar and enzyme supplementation on nutrient availability and performance of broilers fed Maritime Canadian wheat. Can. J. Anim. Sci. 85, 493-499.

Selle, P.H., Ravindran, V., Ravindran, G., Pittolo, P.H. \& Bryden, W.L., 2003. Influence of phytase and xylanase supplementation on growth performance and nutrient utilisation of broilers offered wheatbased diets. Asian-Aust. J. Anim. Sci. 16, 394-402. 
Silversides, F.G., Scott, T.A., Korver, D.R., Afsharmanesh, M. \& Hruby, M., 2006. A study on the interaction of xylanase and phytase enzymes in wheat-based diets fed to commercial white and brown egg laying hens. Poult. Sci. 85, 297-305.

Steiner, T., Mosenthin, R., Zimmermann, B., Greiner, R. \& Roth, S., 2007. Distribution of phytase activity, total phosphorus and phytate phosphorus in legume seeds, cereals and cereal by-products as influenced by harvest year and cultivar. Anim. Feed. Sci. Technol. 133, 320-334.

Svihus, B. \& Hetland, H., 2001. Ileal starch digestibility in growing broiler chickens fed on a wheat-based diet is improved by mash feeding, dilution with cellulose or whole wheat inclusion. Br. Poult. Sci. 42, 633-637.

Swennen, Q., Janssens, G.P.J., Millet, S., Vansant, G., Decuypere, E. \& Buyse, J., 2005. Effect of substitution between fat and protein on feed intake and its regulatory mechanisms in broiler chickens: Endocrine functioning and intermediary metabolism. Poult. Sci. 84, 1051-1057.

Vuilleumier, J.P., 1969. The 'Roche yolk colour fan: an instrument for measuring yolk colour. Poult. Sci. 48, 767-779.

Woyengo, T.A. \& Nyachoti, C.M., 2013. Review: Anti-nutritional effects of phytic acid in diets for pigs and poultry: current knowledge and directions for future research. Can. J. Anim. Sci. 93, 9-21.

Wu, G., Liu, Z., Bryant, M.M. \& Roland, D.A., 2006. Comparison of Natuphos and Phyzyme as phytase sources for commercial layers fed corn-soy diet. Poult. Sci. 85, 64-69.

Xiao-Ying, D., Chu-Fen, Y., Sheng-Qiu, T., Qing-Yan, J. \& Xiao-Ting, Z., 2010. Effect and mechanism of glutamine on productive performance and egg quality of laying hens. Asian-Aust. J. Anim. Sci. 23, 1049-1056.

Zaghari, M., 2009. Evaluation of using phytase nutrient equivalency values for layer hens and broiler chickens. J. Agr. Sci. Technol. 11, 57-66. 